\title{
Enhanced lipid-but not carbohydrate-supported mitochondrial respiration in skeletal muscle of PGC-1 alpha overexpressing mice
}

Citation for published version (APA):

Hoeks, J., Arany, Z., Phielix, E., Kornips, C. F. P., Hesselink, M. K. C., \& Schrauwen, P. (2012). Enhanced lipid-but not carbohydrate-supported mitochondrial respiration in skeletal muscle of PGC-1 alpha overexpressing mice. Journal of Cellular Physiology, 227(3), 1026-1033. https://doi.org/10.1002/jcp.22812

Document status and date:

Published: 01/03/2012

DOI:

10.1002/jcp.22812

Document Version:

Publisher's PDF, also known as Version of record

\section{Document license:}

Taverne

Please check the document version of this publication:

- A submitted manuscript is the version of the article upon submission and before peer-review. There can be important differences between the submitted version and the official published version of record.

People interested in the research are advised to contact the author for the final version of the publication, or visit the DOI to the publisher's website.

- The final author version and the galley proof are versions of the publication after peer review.

- The final published version features the final layout of the paper including the volume, issue and page numbers.

Link to publication

\footnotetext{
General rights rights.

- You may freely distribute the URL identifying the publication in the public portal. please follow below link for the End User Agreement:

www.umlib.nl/taverne-license

Take down policy

If you believe that this document breaches copyright please contact us at:

repository@maastrichtuniversity.nl

providing details and we will investigate your claim.
}

Copyright and moral rights for the publications made accessible in the public portal are retained by the authors and/or other copyright owners and it is a condition of accessing publications that users recognise and abide by the legal requirements associated with these

- Users may download and print one copy of any publication from the public portal for the purpose of private study or research.

- You may not further distribute the material or use it for any profit-making activity or commercial gain

If the publication is distributed under the terms of Article $25 \mathrm{fa}$ of the Dutch Copyright Act, indicated by the "Taverne" license above, 


\title{
Enhanced Lipid-But Not Carbohydrate-Supported Mitochondrial Respiration in Skeletal Muscle of PGC-1 $\alpha$ Overexpressing Mice
}

\author{
JORIS HOEKS, ${ }^{*}{ }^{*}$ ZOLT ARANY, ${ }^{2}$ ESTHER PHIELIX,' ESTHER MOONEN-KORNIPS, 'MATTHIJS \\ K.C. HESSELINK, ${ }^{3}$ AND PATRICK SCHRAUWEN'
}

'NUTRIM - School for Nutrition, Toxicology and Metabolism, Department of Human Biology, Maastricht University Medical Center, Maastricht, The Netherlands

${ }^{2}$ Cardiovascular Institute, Beth Israel Deaconess Medical Center, Harvard Medical School, Boston, Massachusetts

${ }^{3}$ NUTRIM - School for Nutrition, Toxicology and Metabolism, Department of Human Movement Sciences,

Maastricht University Medical Center, Maastricht, The Netherlands

\begin{abstract}
Skeletal muscle mitochondrial dysfunction has been linked to several disease states as well as the process of aging. A possible factor involved is the peroxisome proliferator-activated receptor (PPAR) $\gamma$ co-activator I $\alpha$ (PGC-I $\alpha$ ), a major player in the regulation of skeletal muscle mitochondrial metabolism. However, it is currently unknown whether PGC-I $\alpha$, besides stimulating mitochondrial proliferation, also affects the functional capacity per mitochondrion. Therefore, we here tested whether PGC-I $\alpha$ overexpression, besides increasing mitochondrial content, also leads to intrinsic mitochondrial adaptations. Skeletal muscle mitochondria from 10 male, muscle-specific PGC-I $\alpha$ overexpressing mice (PGC- $\mid \alpha \mathrm{Tg}$ ) and 8 wild-type (WT) mice were isolated. Equal mitochondrial quantities were then analyzed for their oxidative capacity by high-resolution respirometry, fuelled by a carbohydrate-derived (pyruvate) and a lipid (palmitoyl-CoA plus carnitine) substrate. Additionally, mitochondria were tested for reactive oxygen species (superoxide) production and fatty acid (FA)induced uncoupling. PGC-I $\alpha \mathrm{Tg}$ mitochondria were characterized by an improved intrinsic mitochondrial fat oxidative capacity as evidenced by pronounced increase in ADP-stimulated respiration $(P<0.00 \mathrm{I})$ and maximal uncoupled respiration $(P<0.00 \mathrm{I})$ upon palmitoyl-CoA plus carnitine. Interestingly, intrinsic mitochondrial capacity on a carbohydrate-derived substrate tended to be reduced. Furthermore, the sensitivity to FA-induced uncoupling was diminished in PGC-I $\alpha \mathrm{Tg}$ mitochondria $(P=0.02)$ and this was accompanied by a blunted reduction in mitochondrial ROS production upon FAs in PGC-I $\alpha$ Tg versus WT mitochondria $(P=0.04)$. Uncoupling protein 3 (UCP3) levels were markedly reduced in PGC-I $\alpha$ Tg mitochondria $(P<0.00 I)$. Taken together, in addition to stimulating mitochondrial proliferation in skeletal muscle, we show here that overexpression of PGC-I $\alpha$ leads to intrinsic mitochondrial adaptations that seem restricted to fat metabolism.
\end{abstract}

J. Cell. Physiol. 227: 1026-1033, 2012. (C) 20II Wiley Periodicals, Inc.

Peroxisome proliferator-activated receptor (PPAR) $\gamma$ coactivator $I \alpha$ (PGC-I $\alpha)$ is a major player in the regulation of mitochondrial metabolism in oxidative tissues such as skeletal muscle. This transcriptional co-factor controls a broad range of oxidative genes, thereby possessing the ability to coordinate the enhanced mitochondrial biogenesis seen in skeletal muscle in response to, for example, exercise training. Indeed, it was shown that PGC-I $\alpha$ protein levels were increased upon contractile activity, both in rat skeletal muscle in vivo and in skeletal muscle cells in culture (Irrcher et al., 2003). Additionally, several transgenic animal models revealed the importance of PGC-I $\alpha$ in the regulation of mitochondrial metabolism. Thus, skeletal muscle tissue from PGC-I $\alpha$ knockout mice is characterized by reduced levels of mitochondrial respiratory chain proteins, a lower mitochondrial yield, and a diminished mitochondrial respiration in permeabilized muscle fibers (Leone et al., 2005). In contrast, muscle-specific overexpression of PGC-I $\alpha$ resulted in a profound increase the expression of oxidative genes and a very apparent fiber type shift towards more oxidative type I muscle fibers (Lin et al., 2002).

Although the role of PGC-I $\alpha$ in regulating mitochondrial metabolism is clear-cut, it is currently unknown whether induction of PGC-I $\alpha$ simply enhances the proliferation of skeletal muscle mitochondria or whether elevated PGC-I $\alpha$ levels also lead to functionally distinctive mitochondria. In other words, does PGC-I $\alpha$ also regulate the intrinsic mitochondrial capacity, that is, the capacity per mitochondrion? This is a relevant question, given the fact that diseases like type 2

Contract grant sponsor: Dutch Diabetes Research Foundation Contract grant number: 2004.00.059.

Contract grant sponsor: Netherlands Organization for Health Research and Development;

Contract grant number: 9120.6050 .

Contract grant sponsor: Netherlands Organization for Scientific Research;

Contract grant numbers: 917.66.359, 918.96.618.

*Correspondence to: Joris Hoeks, NUTRIM School for Nutrition, Toxicology and Metabolism, Maastricht University Medical Center, Department of Human Biology, P.O. Box 616, 6200 MD Maastricht, The Netherlands. E-mail: j.hoeks@maastrichtuniversity.nl

Received 16 March 2011; Accepted 13 April 2011

Published online in Wiley Online Library (wileyonlinelibrary.com), 25 April 2011.

DOI: $10.1002 /$ jcp.228I2 
diabetes mellitus, chronic obstructive pulmonary disease (COPD) but also the aging process are characterized by mitochondrial dysfunction in skeletal muscle tissue (Mogensen et al., 2007; Figueiredo et al., 2008; Phielix et al., 2008; Naimi et al., 20II). Furthermore, this mitochondrial dysfunction is associated with a reduced expression of PGC-I $\alpha$ (Mootha et al., 2003; Patti et al., 2003; Remels et al., 2007; Anderson and Prolla, 2009) and successful therapeutic strategies include exercise training and/or an active lifestyle (Meex et al., 20 I0; Safdar et al., 20I I), known to positively affect PGC-I $\alpha$ levels.

In this context, the first aim of the present study was to perform a detailed characterization of isolated skeletal muscle mitochondria from PGC-I $\alpha$ overexpressing mice. To this purpose, we used high-resolution respirometry to determine maximal ADP-stimulated (state 3 ) respiration, oligomycininsensitive (state 4) respiration (reflecting mitochondrial proton leak), and maximally uncoupled (state uncoupled) respiration (reflecting the maximal capacity of the electron transport chain), upon both a lipid- and a carbohydrate-derived substrate.

Furthermore, since the mitochondrial dysfunction that was observed in type 2 diabetes, COPD and aging is possibly caused by elevated oxidative stress (Houstis et al., 2006; Bonnard et al., 2008; Figueiredo et al., 2008; Puente-Maestu et al., 2009) and since overexpression of PGC-I $\alpha$ has been shown to alleviate oxidative stress (Kong et al., 20l0), the secondary aim of the present study was to determine mitochondrial-derived reactive oxygen species (ROS) production in PGC-I $\alpha$ overexpressing mice by electron spin resonance (ESR) spectroscopy.

Our results indicate that PGC-I $\alpha$, next to the positive effects on mitochondrial density, also regulates intrinsic mitochondrial adaptations that seem restricted to fat metabolism.

\section{Materials and Methods}

Animals

Ten male, muscle-specific PGC-I $\alpha$ overexpressing mice (PGC$\mathrm{I} \alpha \mathrm{Tg}$ ), generated as described previously (Lin et al., 2002) were used in the present study. Eight male C57BI/6 mice (Charles River, Maastricht, The Netherlands) were used as controls (WT). The mice were housed on a 12:12 h light-dark cycle (light from 7:00 a.m. to 7:00 p.m.), at $21-22^{\circ} \mathrm{C}$ and had free access to standard chow diet (ssniff ${ }^{\mathbb{R}} \mathrm{r} / \mathrm{m}-\mathrm{h} 10 \mathrm{~mm}$, Bio Services, Uden, The Netherlands) and tap water. All experiments were approved by the Animal Care and Use Committee of the Maastricht University and complied with the principles of laboratory animal care.

\section{Tissue collection and mitochondrial isolation}

Mice were sedated by a mixture of $79 \% \mathrm{CO}_{2}$ and $21 \% \mathrm{O}_{2}$ and sacrificed by decapitation. Skeletal muscle tissue of both hind limbs was rapidly dissected and placed into ice-cold mitochondrial isolation buffer $(\sim 15 \mathrm{ml})$ containing $100 \mathrm{mM}$ sucrose, $50 \mathrm{mM} \mathrm{KCl}$, $20 \mathrm{mM} \mathrm{K}^{+}$-TES, I mM EDTA and $0.2 \%(\mathrm{w} / \mathrm{v})$ fatty acid (FA)-free BSA. The muscle tissue was freed of white adipose and connective tissue, weighed and used for isolation of skeletal muscle mitochondria as described previously (Shabalina et al., 2010), with slight modifications. Thus, tissues were finely minced with precooled scissors and homogenized in a potter homogenizer with a teflon pestle in the presence of $\sim 8$ units/g of tissue proteinase Subtilisin (Sigma-Aldrich, St. Louis, MO). Tissue homogenates were centrifuged at $8,500 \mathrm{~g}$ for 10 min at $4^{\circ} \mathrm{C}$ using a Beckman $\mathrm{J2}$ $M C$ centrifuge and the resulting pellets were resuspended and subsequently centrifuged at $800 \mathrm{~g}$ for $10 \mathrm{~min}$. Then, the supernatants were centrifuged at $8,500 \mathrm{~g}$ for $10 \mathrm{~min}$ after which the final mitochondrial pellets were resuspended by hand-

homogenization in a small glass homogenizer in isolation medium. Mitochondrial protein concentration was measured using fluorescamine (Fluram ${ }^{\mathbb{R}}$, Fluka, Zwijndrecht, The Netherlands) with BSA as a standard (Udenfriend et al., 1972) and the remaining mitochondria were stored at $-80^{\circ} \mathrm{C}$ in the presence of a proteinase inhibitor cocktail (Complete Mini, Roche) for additional analyses (see below).

\section{Oxygen consumption in isolated mitochondria}

Mitochondrial respiratory rates of freshly isolated mitochondria were measured at $37^{\circ} \mathrm{C}$ by polarographic oxygen sensors in a twochamber Oxygraph (OROBOROS ${ }^{\circledR}$ Instruments, Innsbruck, Austria). Mitochondrial function was characterized using a carbohydrate-derived substrate ( $5 \mathrm{mM}$ pyruvate) and a FA-derived substrate $(50 \mu \mathrm{M}$ palmitoyl-CoA plus $2 \mathrm{mM}$ carnitine). For this purpose, mitochondria $(0.2 \mathrm{mg}$ for pyruvate and $0.5 \mathrm{mg}$ for palmitoyl-CoA plus carnitine) were incubated in a medium consisting of $100 \mathrm{mM}$ sucrose, $20 \mathrm{mMK}^{+}$-Tes (pH 7.2), $50 \mathrm{mM} \mathrm{KCl}$, $2 \mathrm{mMMgCl}$, I mMEDTA, $4 \mathrm{mMKH}_{2} \mathrm{PO}_{4}, 3 \mathrm{mM}$ malate and $0.1 \%$ of FA-free BSA. Maximal coupled (state 3 ) respiration was initiated by addition of $450 \mu$ M of ADP. State 4 respiration was measured as the residual respiration following addition of $\mathrm{I} \mu \mathrm{g} / \mathrm{ml}$ oligomycin. Maximal oxygen flux rates (state uncoupled) were obtained by titration of the chemical uncoupler carbonyl cyanide $p$ trifluoromethoxyphenylhydrazone (FCCP) in a concentration of 0.75-2.0 $\mu \mathrm{M}$, dependent on the amount necessary to induce maximal mitochondrial respiration.

Fatty acid (FA)-induced respiration uncoupled from ATP synthesis was determined as a marker for FA-induced uncoupling. Thus, increasing amounts of palmitate were automatically titrated (OROBOROS ${ }^{\mathrm{R}}$ Instruments, Innsbruck, Austria) to $0.4 \mathrm{mg}$ mitochondria in the presence of $5 \mathrm{mM}$ pyruvate as a substrate and oligomycin $(I \mu \mathrm{g} / \mathrm{ml})$ to block ATP synthesis (state 4o respiration) while respiration was monitored. The free concentrations of FAs were calculated using the equation described in (Richieri et al., 1999) for the binding of FA to BSA at $37^{\circ} \mathrm{C}$. Data for FA concentration-response curves were analyzed with the four parameter logistic curve fit option of the Sigmaplot 8.0 application.

All substrates were dissolved in double distilled water except palmitate and FCCP/oligomycin, which were dissolved in $50 \%$ and $96 \%$ ethanol, respectively.

\section{Electron spin resonance spectroscopy (ESR)}

ESR spectroscopy was performed principally as described before (Hoeks et al., 2008), to analyze mitochondrial superoxide anion radical production in freshly isolated mitochondria under state 4 conditions. Briefly, mitochondria were diluted in the same medium as for the respiration measurements $(0.1 \mathrm{mg} / \mathrm{ml})$ and incubated for $5 \mathrm{~min}$ at $37^{\circ} \mathrm{C}$. Immediately after incubation, $100 \mathrm{mM}$ activated charcoal purified 5,5-dimethyl-I-pyrolline $\mathrm{N}$-oxide (DMPO) (Sigma-Aldrich) and substrate ( $5 \mathrm{mM}$ pyruvate) was added. To study the effects of FA-induced uncoupling on mitochondrial superoxide production, mitochondria were also analyzed in the presence of $70 \mu \mathrm{M}$ palmitate (before correction for binding to BSA) with pyruvate as a substrate.

Superoxide anion radical derived DMPO-OH' signals, previously shown to be completely inhibited by superoxide dismutase (SOD) (Nabben et al., 2008), were measured on a Bruker EMX 1273. Quantification of the spectra was performed by peak height measurements using the WIN-EPR spectrum program (Bruker, Rheinstetten, Germany).

\section{Western blot analyses}

Western blotting was performed with equal amounts of mitochondrial protein. Blots were blocked with Licorblockingbuffer (Westburg, Leusden, The Netherlands) and incubated overnight (RT) with the primary antibody against UCP3 (Hoeks et al., 2003) and adenine nucleotide translocase I (ANTI) (MitoSciences, Eugene, OR, USA). After incubation with the appropriate secondary antibodies, specific protein bands were 
analyzed in arbitrary units (AU) with the Odyssey Near Infrared Imager (Licor, Westburg, Leusden, The Netherlands).

\section{Citrate synthase and $\beta$-hydroxyacyl CoA dehydrogenase activity}

Equal amounts of mitochondrial protein were analyzed spectrophotometrically for citrate synthase (CS) and $\beta$ hydroxyacyl dehydrogenase ( $\beta$-HAD) activity as previously described (Shephard and Garland, 1969; Bergmeyer et al., 1974).

\section{Statistical analysis}

Results are presented as mean \pm SEM. Statistical analyses were performed with SPSS I 6.0 for Mac software (SPSS Inc., Chicago, IL). Differences between groups were determined with two-sided unpaired Student's t-tests. Outcomes were considered statistically significant if $P<0.05$.

\section{Results}

\section{Mitochondrial yield}

The wet weights of the combined skeletal muscles excised from both hind limbs were similar between genotypes $(\mathrm{I} .67 \pm 0.2 \mathrm{I} \mathrm{g}$ vs. I. $77 \pm 0.14 \mathrm{~g}$ in WT vs. PGC-I $\alpha \mathrm{Tg}$, respectively, $P=0.94)$. As anticipated, the mitochondrial yield (Fig. IA) from skeletal muscle tissue was $\sim 4.5$-fold higher in PGC-I $\alpha \mathrm{Tg}$ mice, as compared to WT $(8.9 \pm 1.6 \mathrm{mg}$ vs. $40.8 \pm 3.4 \mathrm{mg}$ mitochondrial protein/g muscle tissue, $P<0.00 \mathrm{I})$.

\section{Intrinsic mitochondrial respiration}

Mitochondrial oxygen consumption rates in isolated mitochondria on the carbohydrate-derived substrate pyruvate and the lipid-derived substrate palmitoyl-CoA (in the presence of carnitine) are displayed in Figure IB,C, respectively.

Interestingly, ADP-stimulated respiration fuelled by pyruvate tended to be lower in PGC-I $\alpha \mathrm{Tg}$ mice (Fig. IB,D, $P=0.08$ ) whereas oligomycin-insensitive (state 40 ) respiration, reflecting mitochondrial proton leak, was significantly higher in PGC-I $\alpha \mathrm{Tg}$ mice as compared to the WT control group (I $3.7 \pm 0.5 \mathrm{nmol} \mathrm{O}_{2} / \mathrm{min} / \mathrm{mg}$ vs. I $7.4 \pm 0.8 \mathrm{nmol} \mathrm{O} \mathrm{O}_{2} / \mathrm{min} / \mathrm{mg}$ in WT vs. PGC-I $\alpha \mathrm{Tg}$, respectively, $P=0.002$ ). Maximal uncoupled respiration upon pyruvate, reflecting the maximal capacity of the electron transport chain on the given substrate, was unaffected in PGC-I $\alpha \mathrm{Tg}$ mice $\left(382.4 \pm 17.1 \mathrm{nmol} \mathrm{O}_{2} / \mathrm{min} /\right.$ $\mathrm{mg}$ vs. $396.5 \pm 18.7 \mathrm{nmol} \mathrm{O}_{2} / \mathrm{min} / \mathrm{mg}$ in WT vs. PGC-I $\alpha \mathrm{Tg}$, respectively, $P=0.60)$.

In contrast, maximal ADP-stimulated respiration fuelled by the lipid substrate carnitine plus palmitoyl-CoA was enhanced considerably in PGC-I $\alpha \mathrm{Tg}$ mice as compared to WT mice (Fig. IC,E, $P<0.00 \mathrm{I}$ ). Also state 40 respiration (I $3.2 \pm 0.4 \mathrm{nmol} \mathrm{O}_{2} / \mathrm{min} / \mathrm{mg}$ vs. $20.7 \pm \mathrm{I} .1 \mathrm{nmol} \mathrm{O}_{2} / \mathrm{min} / \mathrm{mg}$ in WT vs. PGC-I $\alpha \mathrm{Tg}$, respectively, $P<0.001)$ and maximal uncoupled respiration $\left(103.8 \pm 3.6 \mathrm{nmol} \mathrm{O}_{2} / \mathrm{min} / \mathrm{mg}\right.$ vs. $159.4 \pm 6.2 \mathrm{nmol} \mathrm{O}_{2} / \mathrm{min} / \mathrm{mg}$ in WT vs. PGC-I $\alpha \mathrm{Tg}$, respectively, $P<0.00 \mathrm{I}$ ) on the lipid substrate were significantly higher in PGC-I $\alpha \mathrm{Tg}$ mice.

\section{FA-induced uncoupling}

As anticipated, FA titration stimulated mitochondrial respiration that is not coupled to ATP production (i.e., FAinduced uncoupling) in both genotypes in a dose-dependent manner (Fig. 2A,B). However, mitochondria from PGC-I $\alpha \mathrm{Tg}$ mice displayed a reduced sensitivity for the uncoupling effects of $\mathrm{FAs}$, as evidenced by a significantly elevated $\mathrm{EC}_{50}$ value $(P=0.02$, Fig. 2C), that is, a higher FA concentration is needed in order to induce $50 \%$ of maximal uncoupling. At the same time, PGC- I $\alpha$ Tg mitochondria tended to reach a higher level of maximal uncoupling, indicated by an increased $V_{\max }$ value $(P=0.07$, Fig. 2C).

\section{Mitochondrial superoxide production}

A representative example of a superoxide anion radical derived DMPO-OH ${ }^{\bullet}$ spectrum is shown in Figure $3 \mathrm{~A}$. Mitochondrial superoxide production under state 4 conditions was similar in PGC- $I \alpha$ Tg versus WT mice (Fig. 3C, $P=0.45$ ). Incubation with palmitate, leading to FA-induced uncoupling, significantly decreased mitochondrial superoxide production in WT mice $(P<0.00 \mathrm{I}, \mathrm{Fig} .3 \mathrm{~B})$. Although incubation with $\mathrm{FA}$ also reduced superoxide production in PGC- $I \alpha \mathrm{Tg}$ mitochondria, this decrease was significantly less pronounced (Fig. $3 C, P=0.04$ ).

\section{Mitochondrial proteins and enzyme activities}

Mitochondrial UCP3 levels were markedly reduced in PGCI $\alpha \mathrm{Tg}$ mice and averaged only $\sim 29 \%$ of the levels observed in WT mice $(P<0.00 \mathrm{I}$, Fig. 4A). In contrast, ANTI was significantly elevated in mitochondria from PGC-I $\alpha \mathrm{Tg}$ mice as compared to WT mitochondria $(P=0.02$, Fig. $4 B)$.

We also determined $C S$ and $\beta-H A D$ activity per mitochondrion, that is, expressed per $\mathrm{mg}$ of mitochondrial protein (Fig. 5). This analysis revealed that both $C S(P<0.001$, Fig. 5A $)$ and $\beta-\operatorname{HAD}(P=0.01$, Fig. 5B) activity were significantly enhanced in isolated mitochondria from PGC-I $\alpha \mathrm{Tg}$ mice, by $\sim$ I.6- and $\sim 1.5$-fold, respectively.

\section{Total ATP production capacity}

The results on oxygen consumption rates in isolated skeletal muscle mitochondria presented above, reflect the intrinsic mitochondrial capacity (i.e., per mitochondrion) fuelled by pyruvate and palmitoyl-CoA + carnitine and were expressed per $\mathrm{mg}$ mitochondrial protein. To extrapolate these findings to whole muscle, we estimated the total ATP production capacity per gram of muscle (Table I) by multiplying the mitochondrial yield by the ATP synthesis rate. This analysis revealed that the total ATP production rate is significantly elevated in PGC-I $\alpha \mathrm{Tg}$ mice as compared to WT mice, both on pyruvate ( $\sim$-fold, $P<0.00 I)$ and on carnitine + palmitoyl-CoA $(\sim 8.5$-fold, $P<0.001)$.

\section{Discussion}

The transcriptional co-activator PGC-I $\alpha$ is known to have profound effects on skeletal muscle mitochondrial metabolism and mitochondrial density in particular. It remains to be established however, whether PGC-I $\alpha$ also regulates the intrinsic capacity of skeletal muscle mitochondria, that is, the functional capacity per mitochondrion. In this context, we here extensively characterized isolated mitochondria from PGC-I $\alpha$ overexpressing mice and found that induction of PGC-I $\alpha$, next to increasing mitochondrial mass, also leads to intrinsic mitochondrial adaptations that specifically relate to mitochondrial fat metabolism.

The present study shows that mitochondrial respiration in PGC-I $\alpha$ Tg mice is drastically enhanced upon a FA substrate (palmitoyl-CoA + carnitine) but not upon the carbohydratederived substrate pyruvate. Thus, both ADP-stimulated respiration and maximal uncoupled respiration were significantly enhanced in PGC-I $\alpha \mathrm{Tg}$ mice upon palmitoylCoA + carnitine, indicating an enhanced capacity for fat oxidation, electron transport and of the phosphorylation system. These findings are in line with a recent study showing that mitochondrial respiration rates in PGC-I $\alpha$ knockout mice were dramatically reduced when fuelled with palmitoylcarnitine as a substrate (Zechner et al., 2010). However, whereas the pyruvate-supported mitochondrial respiration in the present study was similar between WT and PGC-I $\alpha \mathrm{Tg}$ mice, Zechner et al. (2010) observed substantial reductions in respiration rates in PGC-l $\alpha$ knockout mice upon pyruvate. Apparently, PGC-I $\alpha$ is required to render a normal capacity for 

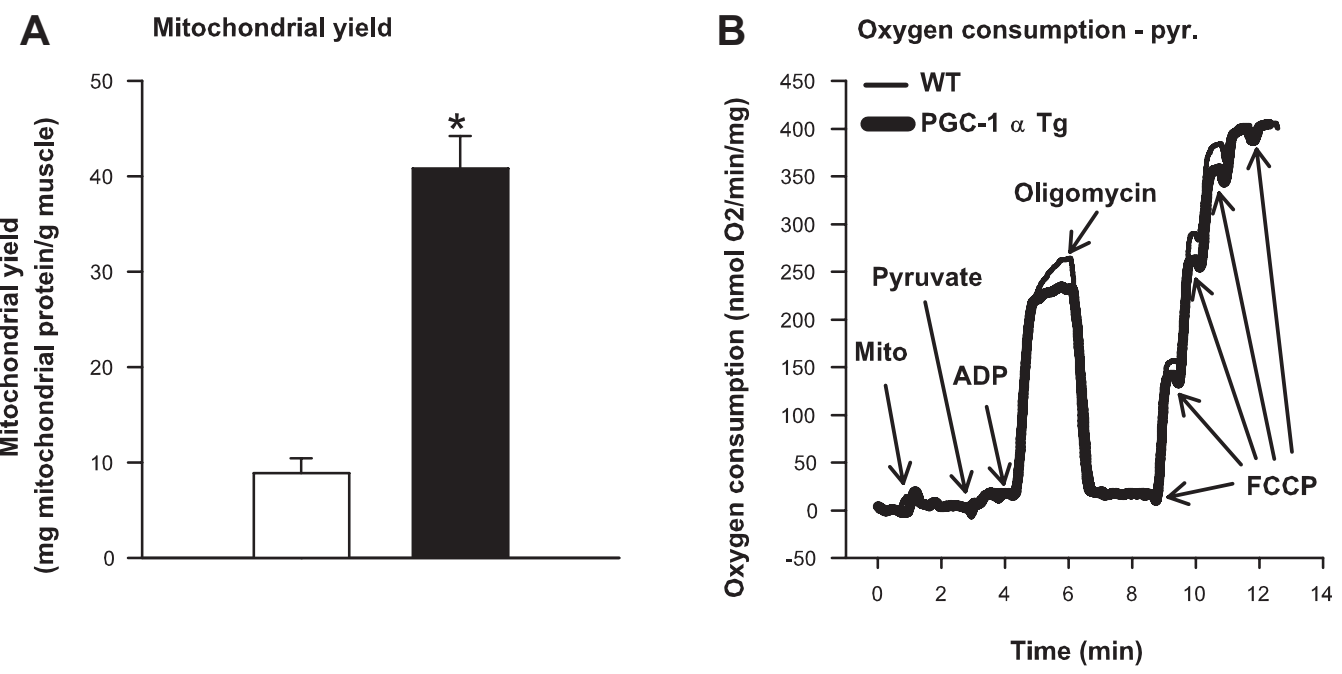

Oxygen consumption
Carnitine + palmCoA

D ADP-stimulated rate
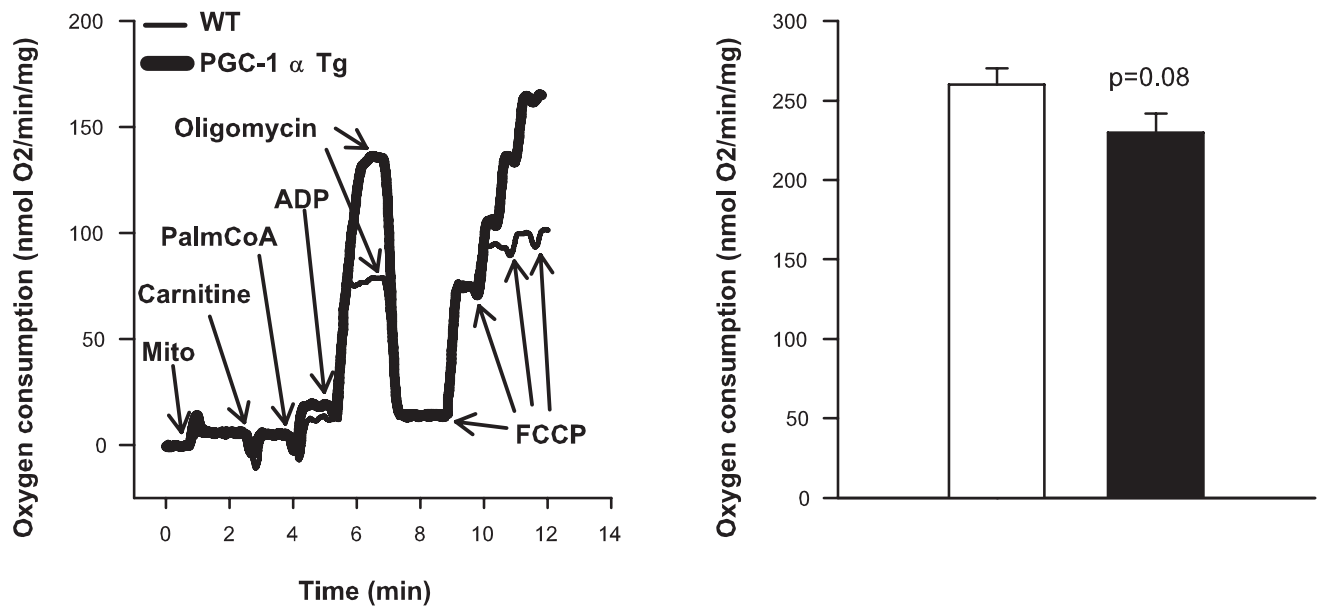

E $\quad$ ADP-stimulated rate

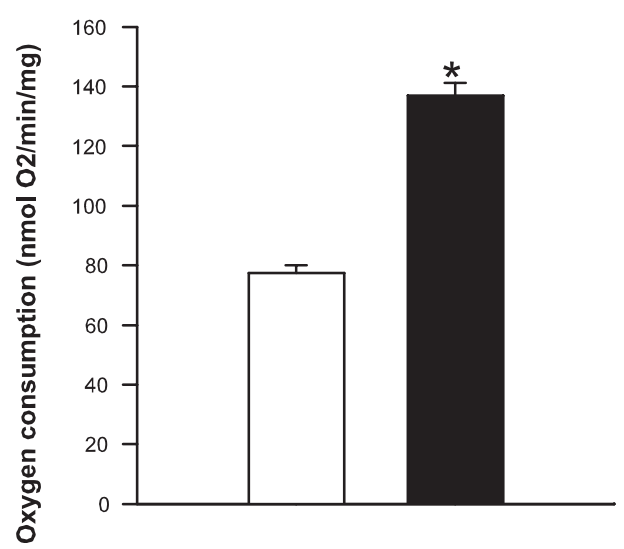

Fig. I. A: Mitochondrial yield from combined skeletal muscle from both hind limbs of WT versus PGC-I $\alpha$ Tg mice $(n=7-8)$. B,C: Representative recordings from oxygen consumption measurements of skeletal muscle mitochondria isolated from WT (thin lines) or PGC-I $\alpha$ Tg (thick lines) mice, fuelled by either pyruvate (B) or carnitine + palmitoyl-CoA (C). D,E: Mitochondrial ADP-stimulated respiration upon (D) pyruvate and (E) carnitine + palmitoyl-CoA in WT versus PGC-I $\alpha$ Tg mice $(n=8-10)$. WT mitochondria are depicted by the white bars while the black bars represent the PGC-I $\alpha$ Tg mitochondria. The values represent the means \pm SEM. ${ }^{*} P<0.05$. 

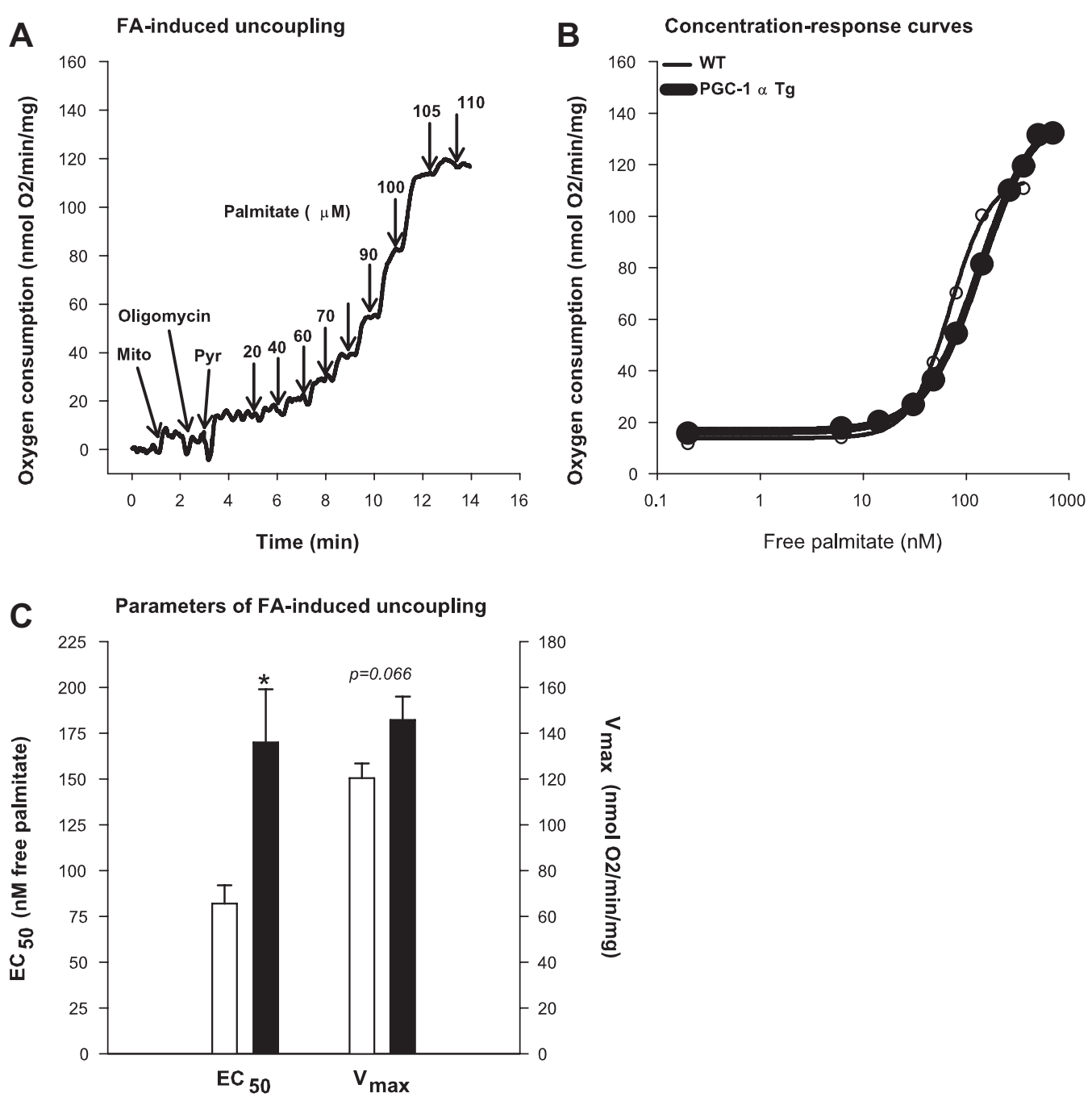

Fig. 2. A: Typical experiment assessing fatty acid-induced uncoupling, that is, monitoring oxygen consumption while titrating mitochondria with palmitate with pyruvate as a substrate and in the presence of oligomycin to block ATP synthesis. B: Palmitate concentration-oxygen consumption response curves in skeletal muscle mitochondria from WT versus PGC-I $\alpha \operatorname{Tg}$ mice $(n=8-10)$. The open symbols and thin line represent WT mitochondria, while filled symbols and thick line indicate mitochondria isolated from PGC-I $\alpha$ Tg mice. C: Parameters of palmitate concentration-response curves of skeletal muscle mitochondria from WT versus. PGC- $\alpha$ Tg mice $(n=8-10)$. PGC- $\mid \alpha T g$ mitochondria (black bars) show a decreased sensitivity for FA-induced uncoupling, evidenced by a significantly increased $E C_{50}$ value as compared to WT mitochondria (white bars). PGC-I $\alpha \mathrm{Tg}$ mitochondria also tolerate higher concentrations of fatty acids as reflected by higher absolute levels of maximal FA-induced uncoupling $\left(V_{\max }\right)$. The values represent the means $\pm S E M$. ${ }^{*} P<0.05$.

pyruvate-supported mitochondrial respiration but overexpression of the co-activator does not further enhance the mitochondrial capacity upon this carbohydrate-derived substrate. This in contrast to the mitochondrial capacity for FA oxidation, which can be enhanced further by overexpressing PGC-I $\alpha$ over basal levels.

In agreement with previous studies (Lin et al., 2002; Choi et al., 2008; Wenz et al., 2009) we also found that the mitochondrial yield from I $g$ of combined muscle tissue is about 4.5-fold higher in PGC-I $\alpha$ Tg mice, as compared to WT. Thus, although mitochondrial respiration upon the carbohydratederived substrate pyruvate tended to be reduced by PGC-I $\alpha$ overexpression, PGC-I $\alpha \mathrm{Tg}$ mice display an enhanced capacity to produce ATP when expressed per gram of muscle tissue, both on carbohydrate and lipid substrates (Table I). For carbohydrates, this is however fully accounted for by the increase in mitochondrial mass, whereas for lipids, the elevated ATP production capacity results from an increased intrinsic mitochondrial capacity in combination with an augmented mitochondrial density.

Although the genetic overexpression of PGC-I $\alpha$ is key in causing the abovementioned changes it is interesting to note that the subcellular localization of PGC-I $\alpha$ may also be of importance for its regulatory role in mitochondrial metabolism. Thus, it was recently shown that PGC-I $\alpha$ is also localized inside mitochondria possibly mediating the cross talk between the nuclear and the mitochondrial genome to promote mitochondrial biogenesis (Aquilano et al., 20I0). In this context, it was also shown that an acute bout of endurance exercise in mice increased both the nuclear and the mitochondrial abundance of PGC-I $\alpha$ (Safdar et al., 20II), indicating that relocation of PGC-I $\alpha$ is of importance for the adaptive response to exercise.

In the present study, PGC-I $\alpha \mathrm{Tg}$ mice also showed an increased mitochondrial CS and $\beta-H A D$ activity, indicative of an enhanced capacity of both the TCA cycle and $\beta$-oxidation per 

A WT - State 4
B WT - State 4 + FA
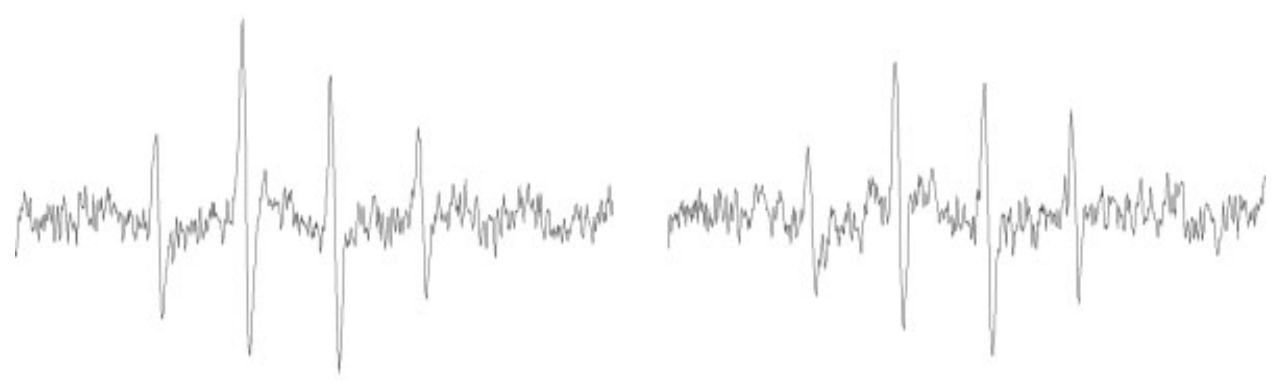

C Mitochondrial superoxide production

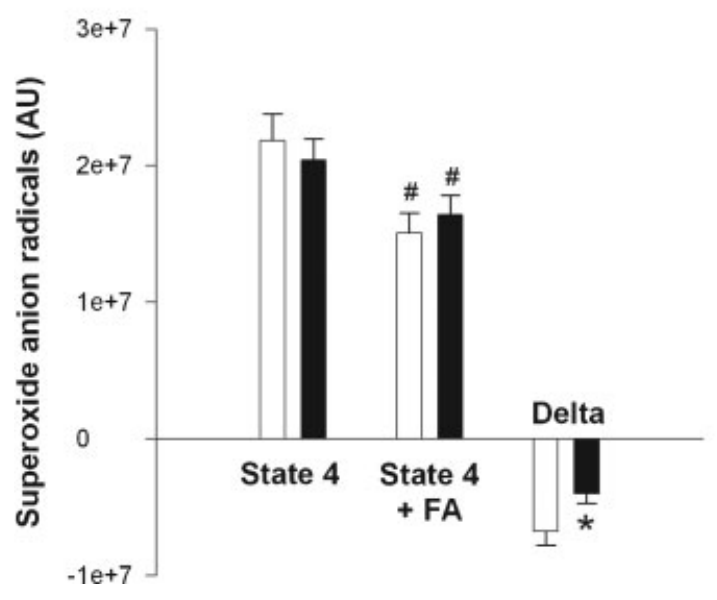

Fig. 3. A: Representative ESR spectrum of WT skeletal muscle mitochondria $(0.1 \mathrm{mg} / \mathrm{ml})$ at $37^{\circ} \mathrm{C}$ in the presence of $100 \mathrm{mM}$ DMPO, reflecting mitochondrial superoxide anion radical production in WT mitochondria under state 4 conditions. B: Similar to A but in the presence of $70 \mu M$ palmitate to stimulate FA-induced uncoupling. FA-induced uncoupling clearly diminishes mitochondrial superoxide anion radical production, directly visible as a reduction of the peak heights. C: Quantification of mitochondrial superoxide anion radical production under state 4 conditions in the absence and presence of palmitate for both WT (white bars) and PGC-I $\alpha \mathrm{Tg}$ (black bars) mice $(n=8-9)$. The decrease in superoxide anion radical production upon palmitate ("delta") was calculated by subtracting the superoxide anion radical production under state 4 conditions in the presence ofFA from the superoxide radical signal under (basal) state 4 conditions (i.e., in the absence of FA). The reduced sensitivity for FA-induced uncoupling (see Fig. 2) in PGC-I $\alpha$ Tg mitochondria is reflected in a blunted reduction of mitochondrial superoxide anion radical production upon palmitate. The values represent the means $\pm S E M .{ }^{\#} P<0.05$ for state $4+$ FA versus state $4,{ }^{*} P<0.05$ for WT versus $P G C-I \alpha T g$.

mitochondrion. Interestingly however, UCP3 was profoundly reduced indicating that the overexpression of PGC-I $\alpha$ does not merely enhance all proteins related to mitochondrial metabolism. UCP3 has been implicated in the regulation of mitochondrial ROS production via mild uncoupling, that is, a lowering of the mitochondrial proton gradient that is not coupled to ATP synthesis (Echtay et al., 2002; Echtay et al., 2003; Brand et al., 2004). However, despite clearly lowered UCP3 protein levels in PGC-I $\alpha$ Tg mice, oligomycin-insensitive (state 40 ) respiration, indicative for mitochondrial proton leak, was higher rather than lower in PGC-I $\alpha$ Tg mice. Furthermore, we did not observe differences in mitochondrial superoxide production in PGC-I $\alpha \mathrm{Tg}$ versus WT mice under state 4 conditions. In other words, the net amount of mitochondrial superoxide that leaves the mitochondria under these conditions is similar between PGC-I $\alpha \mathrm{Tg}$ and WT mitochondria, despite a reported increase in mitochondrial superoxide dismutase 2 (SOD2) in PGC-I $\alpha \mathrm{Tg}$ mice (Wenz et al., 2009). It cannot be excluded however, that the intramitochondrial superoxide production is increased in PGC$\mathrm{I} \alpha \mathrm{Tg}$ mice, which is normalized by enhanced mitochondrial anti-oxidant defense mechanisms.
Although the reduced UCP3 protein content in PGC-I $\alpha \mathrm{Tg}$ mitochondria did not affect basal state 4 respiration and/or superoxide producing capacity, it has been suggested that UCP3 needs to be activated by FAs, in order to display its uncoupling and ROS-lowering properties (Zackova and Jezek, 2002; Esteves and Brand, 2005). Therefore, we tested the capacity for FA-induced uncoupling and indeed found thatconsistent with lower UCP3 levels - this was reduced in mitochondria from PGC-I $\alpha$ overexpressing mice, as evidenced by a significantly elevated $\mathrm{EC}_{50}$ value (Fig. $\left.2 \mathrm{~B}, \mathrm{C}\right)$. Interestingly however, the maximal uncoupling capacity $\left(\mathrm{V}_{\max }\right)$ that could be induced by FAs tended to be increased, rather than decreased, in PGC-I $\alpha$ Tg mice as compared to WT animals (Fig. 2C). These changes were also accompanied by an elevated level of ANTI, the mitochondrial ADP/ATP anti-porter that has also been implicated in FA-induced uncoupling (Skulachev, 1991).

Taken together, PGC-I $\alpha \mathrm{Tg}$ mitochondria are less sensitive to the uncoupling effects of FAs but can tolerate higher concentrations of FAs leading to higher absolute levels of maximal FA-induced uncoupling. Given the potential ROSlowering effect of mitochondrial uncoupling we then tested whether the observed differences in FA-induced uncoupling 
A

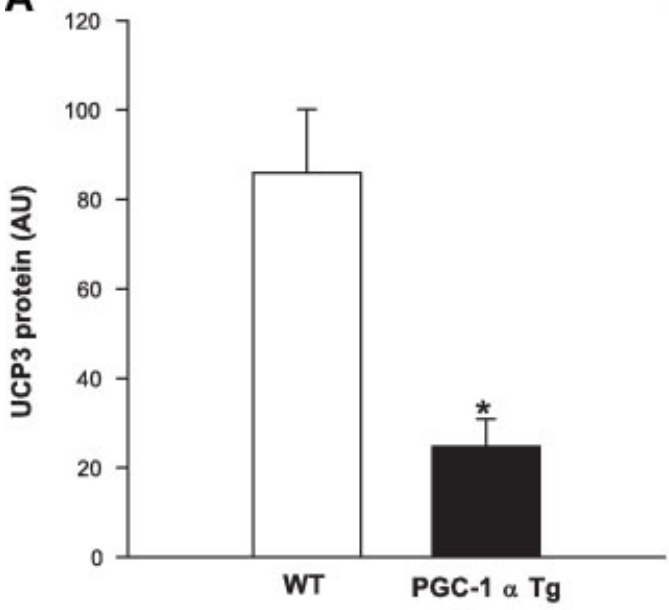

UCP3
M Mitochondrial ANT1 content
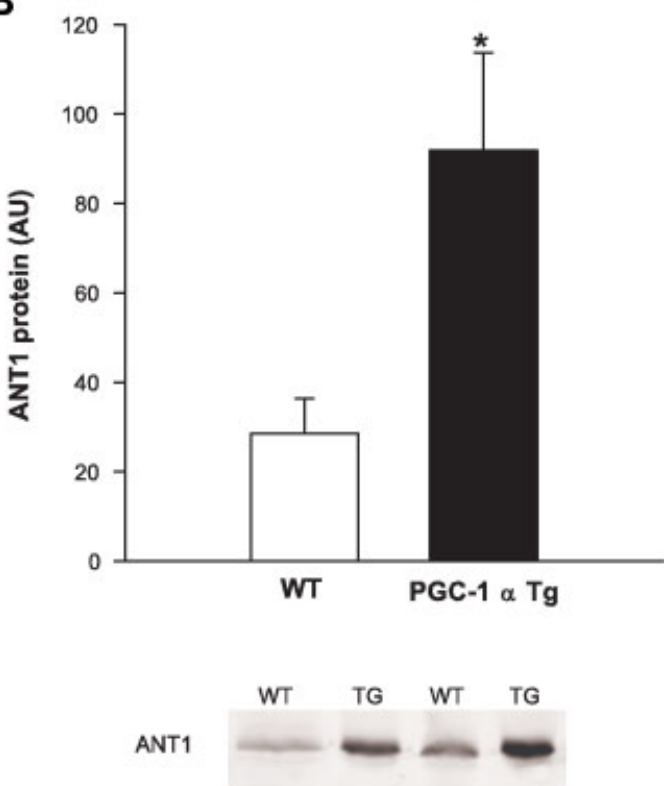

Fig. 4. Quantification of Western blot analyses for (A) mitochondrial uncoupling protein 3 (UCP3) and (B) adenine nucleotide translocator (ANTI) in skeletal muscle mitochondria, including representative immunoblots. WT mitochondria are depicted by the white bars while the black bars represent the PGC-I $\alpha \mathrm{Tg}$ mitochondria. Values are expressed as mean $\pm \mathrm{SEM}$. ${ }^{*} P<0.05$.

were reflected in differences in mitochondrial ROS production upon FA loading.

Indeed, our data show that FA-induced uncoupling significantly reduced mitochondrial superoxide production under state 4 conditions in both genotypes. Furthermore, the reduced capacity for FA-induced uncoupling in PGC-I $\alpha$ Tg mice was also reflected in a significantly less pronounced reduction in mitochondrial superoxide production upon FAs under these conditions (Fig. 3C).

In summary, mitochondria isolated from PGC-I $\alpha$ Tg mice clearly favor a FA- over a carbohydrate-derived substrate.
Additionally, CS (citric acid cycle) and $\beta$-HAD ( $\beta$-oxidation) activity were both significantly elevated when expressed per mitochondrion, whereas skeletal muscle UCP3 content was lowered considerably in PGC-I $\alpha \mathrm{Tg}$ mice. Despite these changes in UCP3, basal mitochondrial uncoupling was however unchanged whereas the capacity for FA-induced uncoupled was diminished in PGC-I $\alpha \mathrm{Tg}$ mice. Our results show that PGC-I $\alpha$ does not merely increase the formation of new skeletal mitochondria but clearly leads to intrinsic mitochondrial adaptations that seem restricted to FA metabolism.
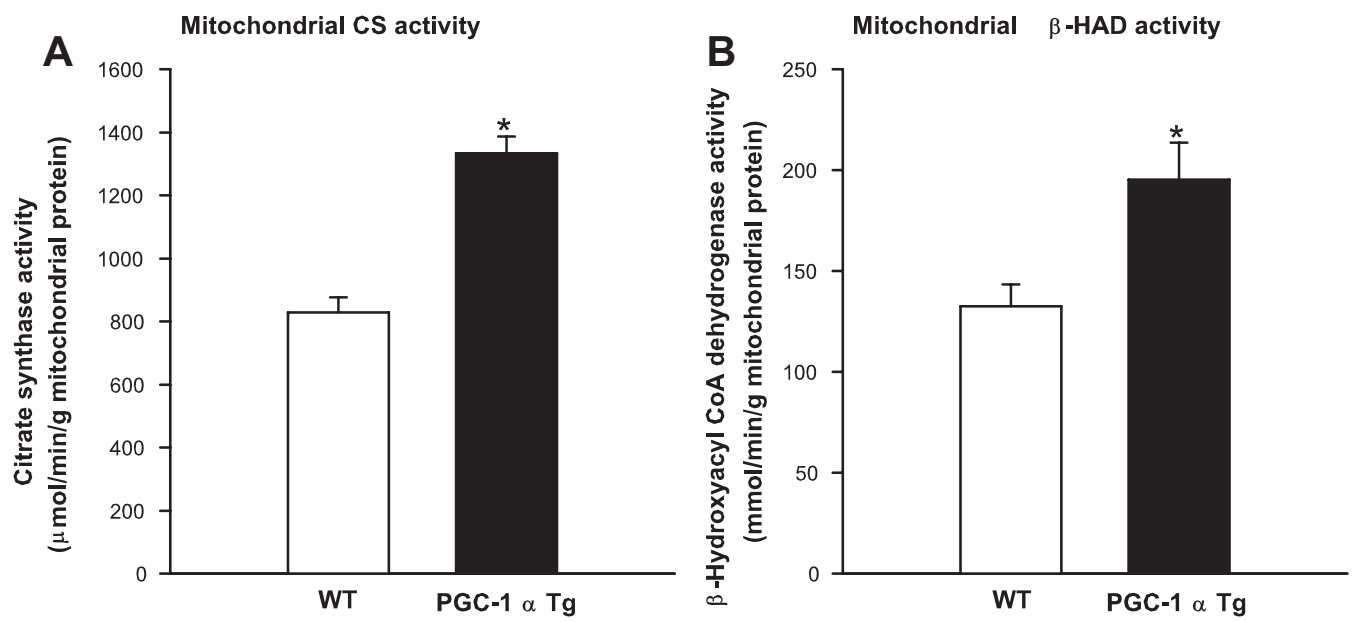

Fig. 5. A: Citrate synthase (CS) and (B) $\beta$-hydroxyacyl dehydrogenase ( $\beta$-HAD) activity in isolated skeletal muscle mitochondria from WT (white bars) and PGC-I $\alpha \mathrm{Tg}$ (black bars) mice. Values are expressed as mean \pm SEM. ${ }^{*} P<0.05$. 
TABLE I. Total mitochondrial ADP phosphorylation capacity in skeletal muscle

\begin{tabular}{lcc}
\hline & \multicolumn{2}{c}{ Substrate } \\
\cline { 2 - 3 } Genotype & Pyruvate & Carnitine + Palmitoyl-CoA \\
\hline WT & $2,103 \pm 280$ & $549 \pm 80$ \\
PGC-I $\alpha \mathrm{Tg}$ & $8,417 \pm 562^{*}$ & $4,658 \pm 374^{*}$ \\
\hline
\end{tabular}

Total ADP phosphorylation capacity was estimated as the respiratory response (in $\mathrm{nmol} \mathrm{O}_{2}$ $\mathrm{min} / \mathrm{mg}$ mitochondrial protein) to ADP (state 3 respiration) minus oligomycin-insensitive oxygen consumption (state 4 respiration) and multiplied with the mitochondrial yield from the same animal. Values represent the means \pm SEM of seven to eight separate experiments. ${ }^{*} P<0.05$.

\section{Acknowledgments}

J.H. was supported by a grant from the Netherlands Organization for Health Research and Development (ZonMW, grant $9 \mid 20.6050)$. M.H. is supported by a VIDI Research Grant for innovative research from the Netherlands Organization for Scientific Research (Grant 917.66.359). Dr. P. Schrauwen is supported by a VICl Research Grant for innovative research from the Netherlands Organization for Scientific Research (Grant 918.96.618).

\section{Literature Cited}

Anderson R, Prolla T. 2009. PGC-I alpha in aging and anti-aging interventions. Biochim Biophys Acta 1790:1059-1066.

Aquilano K, Vigilanza P, Baldelli S, Pagliei B, Rotilio G, Ciriolo MR. 2010. Peroxisome proliferator-activated receptor gamma co-activator Ialpha (PGC-Ialpha) and sirtuin I (SIRTI) reside in mitochondria: possible direct function in mitochondrial biogenesis. J Biol Chem 285:21590-21599.

Bergmeyer HU, Gawehn K, Grassl M. 1974. 3-Hydroxyacyl-CoA dehydrogenase. In: Bergmeyer HU, editor. Methods of enzymatic analysis. Weinheim, Germany: Verlag Chemie. P 474

Bonnard C, Durand A, Peyrol S, Chanseaume E, Chauvin MA, Morio B, Vidal H, Rieusset J. 2008. Mitochondrial dysfunction results from oxidative stress in the skeletal muscle of diet2008. Mitochondrial dysfunction results from oxidative stress

Brand MD, Affourtit C, Esteves TC, Green K, Lambert AJ, Miwa S, Pakay JL, Parker N. 2004 Mitochondrial superoxide: Production, biological effects, and activation of uncoupling proteins. Free Radic Biol Med 37:755-767.

Choi CS, Befroy DE, Codella R, Kim S, Reznick RM, Hwang YJ, Liu ZX, Lee HY, Distefano A Samuel VT, Zhang D, Cline GW, Handschin C, Lin J, Petersen KF, Spiegelman BM, Shulman GI. 2008. Paradoxical effects of increased expression of PGC-I alpha on muscle mitochondrial function and insulin-stimulated muscle glucose metabolism. Proc Natl Acad Sci USA 105:19926-19931.

Echtay KS, Esteves TC, Pakay JL, Jekabsons MB, Lambert AJ, Portero-Otin M, Pamplona R, Vidal-Puig AJ, Wang S, Roebuck SJ, Brand MD. 2003. A signalling role for 4-hydroxy-2nonenal in regulation of mitochondrial uncoupling. EMBO J 22:4103-4II0.

Echtay KS, Roussel D, St-Pierre J, Jekabsons MB, Cadenas S, Stuart JA, Harper JA, Roebuck SJ, Morrison A, Pickering S, Clapham JC, Brand MD. 2002. Superoxide activates mitochondrial uncoupling proteins. Nature 415:96-99.

Esteves TC, Brand MD. 2005. The reactions catalysed by the mitochondrial uncoupling proteins UCP2 and UCP3. Biochim Biophys Acta 1709:35-44.

Figueiredo PA, Mota MP, Appell HJ, Duarte JA. 2008. The role of mitochondria in aging of skeletal muscle. Biogerontology 9:67-84

Hoeks J, Briede J], de Vogel J, Schaart G, Nabben M, Moonen-Kornips E, Hesselink MK, Schrauwen P. 2008. Mitochondrial function, content and ROS production in rat skeletal muscle: Effect of high-fat feeding. FEBS Lett 582:5I0-516.

Hoeks J, Hesselink MK, van Bilsen M, Schaart G, van der Vusse GJ, Saris WH, Schrauwen P. 2003. Differential response of UCP3 to medium versus long chain triacylglycerols; manifestation of a functional adaptation. FEBS Lett 555:63I-637.

Houstis N, Rosen ED, Lander ES. 2006. Reactive oxygen species have a causal role in multiple forms of insulin resistance. Nature 440:944-948.
Irrcher I, Adhihetty PJ, Sheehan T, Joseph AM, Hood DA. 2003. PPARgamma coactivatorI alpha expression during thyroid hormone- and contractile activity-induced mitochondrial adaptations. Am J Physiol Cell Physiol 284:Cl669-Cl677.

Kong X, Wang R, Xue Y, Liu X, Zhang H, Chen Y, Fang F, Chang Y. 2010. Sirtuin 3, a new target of PGC-Ialpha, plays an important role in the suppression of ROS and mitochondrial biogenesis. PLoS ONE 5:ell 707

Leone TC, Lehman JJ, Finck BN, Schaeffer PJ, Wende AR, Boudina S, Courtois M, Wozniak DF, Sambandam N, Bernal-Mizrachi C, Chen Z, Holloszy JO, Medeiros DM, Schmidt RE, Saffitz JE, Abel ED, Semenkovich CF, Kelly DP. 2005. PGC-I alpha deficiency causes multisystem energy metabolic derangements: Muscle dysfunction, abnormal weight control and hepatic steatosis. PLoS Biol 3:el0I.

Lin J, Wu H, Tarr PT, Zhang CY, Wu Z, Boss O, Michael LF, Puigserver P, Isotani E, Olson EN, Lowell BB, Bassel-Duby R, Spiegelman BM. 2002. Transcriptional co-activator PGC-I alpha drives the formation of slow-twitch muscle fibres. Nature 418:797-801.

Meex RC, Schrauwen-Hinderling VB, Moonen-Kornips E, Schaart G, Mensink M, Phielix E, van de Weijer T, Sels JP, Schrauwen P, Hesselink MK. 20I0. Restoration of muscle mitochondrial function and metabolic flexibility in type 2 diabetes by exercise training is paralleled by increased myocellular fat storage and improved insulin sensitivity. Diabetes 59:572-579.

Mogensen M, Sahlin K, Fernstrom M, Glintborg D, Vind BF, Beck-Nielsen H, Hojlund K. 2007 Mitochondrial respiration is decreased in skeletal muscle of patients with type 2 diabetes. Diabetes 56:1592-1599.

Mootha VK, Lindgren CM, Eriksson KF, Subramanian A, Sihag S, Lehar J, Puigserver P, Carlsson E, Ridderstrale M, Laurila E, Houstis N, Daly MJ, Patterson N, Mesirov JP, Golub TR, Tamayo P, Spiegelman B, Lander ES, Hirschhorn IN, Altshuler D, Groop LC. 2003 PGC-I alpha-responsive genes involved in oxidative phosphorylation are coordinately downregulated in human diabetes. Nat Genet 34:267-273.

Nabben M, Hoeks J, Briede JJ, Glatz JF, Moonen-Kornips E, Hesselink MK, Schrauwen P. 2008 The effect of UCP3 overexpression on mitochondrial ROS production in skeletal muscle of young versus aged mice. FEBS Lett 582:4I47-4I52.

Naimi Al, Bourbeau J, Perrault H, Baril J, Wright-Paradis C, Rossi A, Taivassalo T, Sheel AW, Rabol R, Dela F, Boushel R. 20I I. Altered mitochondrial regulation in quadriceps muscles of patients with COPD. Clin Physiol Funct Imaging 31:124-131.

Patti ME, Butte AJ, Crunkhorn S, Cusi K, Berria R, Kashyap S, Miyazaki Y, Kohane I, Costello M, Saccone R, Landaker EJ, Goldfine AB, Mun E, DeFronzo R, Finlayson J, Kahn CR, Mandarino LJ. 2003. Coordinated reduction of genes of oxidative metabolism in human with insulin resistance and diabetes: Potential role of PGCI and NRFI. Proc Natl Acad Sc USA 100:8466-847।.

Phielix E, Schrauwen-Hinderling VB, Mensink M, Lenaers E, Meex R, Hoeks J, Kooi ME, Moonen-Kornips E, Sels JP, Hesselink MK, Schrauwen P. 2008. Lower intrinsic ADPstimulated mitochondrial respiration underlies in vivo mitochondrial dysfunction in muscle of male type 2 diabetic patients. Diabetes 57:2943-2949.

Puente-Maestu L, Perez-Parra J, Godoy R, Moreno N, Tejedor A, GonzalezAragoneses F, Bravo JL, Alvarez FV, Camano S, Agusti A. 2009. Abnormal mitochondrial function in locomotor and respiratory muscles of COPD patients. Eur Respir J 33:1045-1052.

Remels AH, Schrauwen P, Broekhuizen R, Willems J, Kersten S, Gosker HR, Schols AM. 2007 Peroxisome proliferator-activated receptor expression is reduced in skeletal muscle in COPD. Eur Respir J 30:245-252.

Richieri GV, Ogata RT, Kleinfeld AM. 1999. The measurement of free fatty acid concentration with the fluorescent probe ADIFAB: A practical guide for the use of the ADIFAB probe. Mol Cell Biochem 192:87-94.

Safdar A, Little JP, StokI AJ, Hettinga BP, Akhtar M, Tarnopolsky MA. 20I I. Exercise increase mitochondrial PGC-I \{alpha\} content and promotes nuclear-mitochondrial cross-talk to coordinate mitochondrial biogenesis. J Biol Chem 286:10605-10617.

Shabalina IG, Hoeks J, Kramarova TV, Schrauwen P, Cannon B, Nedergaard J. 2010. Cold tolerance of UCPI-ablated mice: A skeletal muscle mitochondria switch toward lipid oxidation with marked UCP3 up-regulation not associated with increased basal, fatty acidor ROS-induced uncoupling or enhanced GDP effects. Biochim Biophys Acta 1797:968980.

Shephard D, Garland PB. 1969. Citrate synthase from rat liver. Methods Enzymol I3: I I-16. Skulachev VP. 1991. Fatty acid circuit as a physiological mechanism of uncoupling of oxidative phosphorylation. FEBS Lett 294:158-162.

Udenfriend S, Stein S, Bohlen P, Dairman W, Leimgruber W, Weigele M. 1972

Fluorescamine: A reagent for assay of amino acids, peptides, proteins, and primary amines in the picomole range. Science I78:87I-872.

Wenz T, Rossi SG, Rotundo RL, Spiegelman BM, Moraes CT. 2009. Increased muscle PGCI alpha expression protects from sarcopenia and metabolic disease during aging. Proc $\mathrm{Nat}$ Acad Sci USA 106:20405-20410.

Zackova M, Jezek P. 2002. Reconstitution of novel mitochondrial uncoupling proteins UCP2 and UCP3. Biosci Rep 22:33-46.

Zechner C, Lai L, Zechner JF, Geng T, Yan Z, Rumsey JW, Collia D, Chen Z, Wozniak DF, Leone TC, Kelly DP. 2010. Total skeletal muscle PGC-I deficiency uncouples mitochondrial derangements from fiber type determination and insulin sensitivity. Cell Metab 12:633-642. 